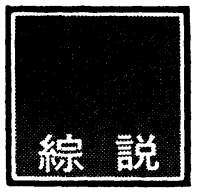

\title{
Thrombolytic Therapy of Peripheral Arterial Occlusions
}

\author{
by
}

\author{
E. Deutsch and H. Ehringer
}

from

The First Department of Medicine University of Vienna, Austria (A special lecture delivered on the 3rd Congress of the Japanese Society on Thrombosis and Hemostasis)

Key words : thrombolytic therapy, peripheral arterial occlusion.

The available data on the frequency and epidemiology of peripheral occlusive arterial disease are not so well established than those of myocardial infarction. The largest epidemiological study in Europe was performed by Widmer and coworkers who studied 6,400 employees of the Basle pharmaceutical companies since 1959. Peripheral occlusive arterial disease was found in $3 \%$ of males with an average age of 50 years, and in $8 \%$ of those with an average age of 70 years, which means that about $5.1 \%$ of the population aged 20 to 70 years has occlusive peripheral arterial disease. This demonstrates the high frequency and the great importance of this type of disease for the general population. The basic process in most of these cases is obliterative arteriosclerosis whereas thrombangitis obliterans and arteritis of various types only a minor role in the etiology of occlusive arterial disease in Europe. The following discussion will therefore concentrate only on the former type of disease.

Arteriosclerosis causes narrowing of the vessels and damage of the endothelial layer.
Platelets adhere to the subendothelial structures, followed by aggregation of more platelets and finally by the formation of a white thrombus. For a long time the general opinion was that blood coagulation and fibrin formation only plays a minor role in the formation of this type of thrombosis. Additionally the platelets are rich in antiplasmin and therefore it was not expected, that effective fibrinolysis would be induced in arterial thrombosis.

The practical experience, however, was at variance to this speculation.

Ardlie and Han have recently demonstrated, that blood clotting is also basically involved in the process of platelet aggregation. Platelets adhering to collagen achieve the ability to activate factor XI (collagen induced coagulating activity) and by it the endogenous clotting system on the surface of the platelet. Thrombin formed on the surface of one platelet binds to a molecule of fibrinogen on the surface of another platelet. This results in reversible platelet aggregation. Then, fibrin is formed and irreversible aggregation is caused by fibrin polymerization. In the mean- 
time platelet constituants are released such as ADP, serotonin, platelet factors 3 and 4 . More platelets aggregate and coagulation is induced in the surrounding blood, and finally a white thrombus is formed which occludes the vessel.

It is owing to Gottlob and his coworkers having studied the lysability of thrombi of various ages in vitro. This authors found that fresh thrombi are easely lysed as expected. However, approximately at the second day, they become resistant against lysis by loss of plasminogen through clot retraction. At the end of the first week the thrombi are swollen and have taken up fluid and plasminogen, and are lysable again. The organization of the thrombi starts much later as formerly suggested and comes to completion only in smaller vessels. Frequently it remains localized to the marginal parts of the thrombi for a long period of time. In large vessels such as aorta or common iliac artery large portions of the thrombi remain unorganized for months and even for years. These facts explain why

(1) anticoagulant and thrombolytic therapy are without beneficial effect in the symmetrical and long type of arterial stenoses, which are predominantly caused by arteriosclerotic thickning of the vessel wall;

(2) anticoagulant and thrombolytic therapy are effective in arterial occlusions and in asymmetrical short arterial stenoses caused by mural thrombi;

(3) occlusions of larger vessels are more easily lysed than those of small vessels;

(4) even very old thrombi in large vessels may be lyzed.

The results of the thrombolytic therapy will be demonstrated on our original material :

\section{Material and Methods}

Our material comprises now 117 patients -101 male and 16 female - with the mean age of 59 years who have been treated with streptokinase. Sixty eight of them have been followed up for a mean period of 2.7 years ( 3 month to 6.5 years). Each patient has been preexamined by oscillography, ankle pressure (Doppler ultrasound), venous occlusion pletysmography and arteriography, and a general check up has been performed to disclose possible contraindications with special reference to gastrointestinal ulcers. The result of the therapy was assessed by the same methods short time after the thrombolytic therapy and at the yearly follow up examinations.

Thrombolysis was induced by the infusion of streptokinase. In the earlier cases the necessary dose of streptokinase was determined by the streptokinase resistance test, but lateron it was found that a standard dose of $400,000 \mathrm{U}$ SK infused within $50 \mathrm{~min}$. routinely induces fibrinolytic activity. The activity was maintained by the infusion of 100,000 $\mathrm{U} / \mathrm{h}$ until functional tests had shown an opening of the arterial occlusion or complications forced us to interrupt the infusion, but not longer than 144 hours if we not succeeded to open the vessel. The mean duration of the therapy was $71.8 \pm 3.1$ hours, the mean amount of SK used $7.9 \pm 3.0$ million units. Now-a-days we prefere standardised infusion time of 72 hours, because it turned out not being worth while continuing the infusion for longer period of time, since the risk of complications is increasing more than the benefit. Before beginning the infusion $50 \mathrm{mg} \%$ of prednisolon was administered. The effect of the therapy was routinely watched by the thrombin time determination of fibrinogen 
Table 1 Rate of thrombolysis-age of occlusions. 221 occlusions in 117 patients.

\begin{tabular}{c|l|c|c|c|c}
\hline Group & Age of occlusion & $\begin{array}{c}\text { Occlusions } \\
\mathrm{N}\end{array}$ & Lysis & $\begin{array}{c}\text { Recurrency } \\
\text { (change over to LTA) }\end{array}$ & $\begin{array}{c}\text { Final rate } \\
\text { of lysis }\end{array}$ \\
\hline 1 & 6 days $\sim 6$ weeks & 88 & $69=78 \%$ & $13=15 \%$ & $56 / 88=64 \%$ \\
2 & 6 weeks $\sim 6$ months & 47 & $8=17 \%$ & 1 & $7 / 47=15 \%$ \\
3 & $>6$ months & 81 & $0=0 \%$ & 0 & $0 / 81^{*}=0 \%$ \\
\hline
\end{tabular}

* Only 1 occlusion of A. iliaca or aorta.

Ehringer, H., et al., 1974-03-31.

and prothrombin either accordingto Quick or with thrombotest. As soon as the streptokinase has neutralized the antistreptokinase present in the plasma, plasminogen activator activity can be demonstrated in the plasma. It is usually maintained until the end of the treatment period. Plasminogen is activated to plasmin and disappears more or less completely from the blood. Fibrinogen is reduced to values below $100 \mathrm{mg} \%$ and sometimes complete afibrinogenemia arises. Thrombin time quickly increases as soon as fibrinolysis is induced in the circulating blood, as result of the reduction of fibrinogen and formation of fibrin degradation products. It was aimed to keep the thrombin time at three times normal. During the course of SK infusion one can notice a tendency of increase of the initially very low fibrinogen values and a decrease of the initially very long thrombin time. This effect is caused by depletion of plasminogen in plasma and reduction of fibrinogenolysis and the level of split products. Sometimes this increase of fibrinogen is very rapid. If the thrombin time was reduced below $30 \mathrm{sec}$, which may happen at the third day of treatment, sometimes even earlier we intend to achieve a reduction of fibrinogen level and an increase of thrombin time by doubling the dose of SK for 12 hours. At the same time we expect to intensify the endogenous thrombolysis. If we do not succeed in the increase of thrombin time we add heparin, since the danger of rethrombosis occurs already at this point. The infusion of SK was interrupted for some hours if the thrombin time was increased over $120^{\prime \prime}$. The thrombolytic therapy has to be followed by anticoagulation for maintenance of the result. This is the most difficult part of the therapy. Heparin was started immediately after completion of SK infusion, either by i. v. infusion of $1,000 \mathrm{U} / \mathrm{h}$ or by s. c. injection of 10,000 to $12,500 \mathrm{U}$ every $8 \mathrm{hrs}$. At the same time phenprocoumon (Marcoumar) treatment was started. The heparin therapy was discontinued as soon as the prothrombin level was in the therapeutic range. 22 patients received Arvin, the venom of the malayan pit viper Agkistrodon rhodostoma instead of heparin by intermittent infusion of $154 \mathrm{U}$ every 12 hours. Marcoumar treatment was started at the same time and the arvin infusions stopped when the prothrombin level was in the therapeutic range.

\section{Results}

\section{Short time results in not acute arterial occlusions.}

117 patients with 216 arterial occlusions have been treated with SK. A total of 77 occlusions or $35.6 \%$ have been opened. As already pointed out in the introduction the success of the therapy depends on the age of the thrombus and on its localisation. If the material therefore is stratified according to the age of the thrombosis, the results of Table 1 are obtained : 88 occlusions were 6 days to 6 weeks old. 69 or $78 \%$ have been 
Table 2 Rate of thrombolysis-age and site of occlusions. (1) Age : 6 days 6 weeks (osslusions only).

\begin{tabular}{l|c|c|c|c}
\hline \multicolumn{1}{c|}{ Site } & $\begin{array}{c}\text { Occlusions } \\
\text { N }\end{array}$ & Lysis & $\begin{array}{c}\text { Recurrency } \\
\text { (change over to LTA) }\end{array}$ & $\begin{array}{c}\text { Final rate of } \\
\text { lysis }\end{array}$ \\
\hline Aorta+A. Iliaca & 13 & $12=92 \%$ & 1 & $11 / 13=85 \%$ \\
A. Femoralis & 38 & $28=74 \%$ & 5 & $23 / 38=61 \%$ \\
A. Poplitea & 20 & $15=75 \%$ & 7 & $8 / 20=40 \%$ \\
A. of the lower leg & 17 & $14=82 \%$ & 0 & $14 / 17=82 \%$ \\
\hline \multicolumn{1}{c|}{ total } & 88 & $69=78 \%$ & $13=15 \%$ & $56 / 88=64 \%$ \\
\hline
\end{tabular}

Ehringer, H., 1974-03-31.

Table 3 Rate of thrombolysis-age and site of occlusion. (2) Age : 6 weeks 6 months (occlusions only).

\begin{tabular}{l|c|c|c|c}
\hline \multicolumn{1}{c|}{ Site } & $\begin{array}{c}\text { Occlusions } \\
\text { N }\end{array}$ & Lysis & $\begin{array}{c}\text { Recurrency } \\
\text { (change over to LTA) }\end{array}$ & $\begin{array}{c}\text { Final rate } \\
\text { lysis }\end{array}$ \\
\hline Aorta+ A. Iliaca & 9 & $3=33 \%$ & 0 & $3 / 9(=33 \%)$ \\
A. Femoralis & 24 & $4=17 \%$ & 1 & $3 / 24=(13 \%)$ \\
A. Poplitea & 6 & 1 & 0 & $1 / 6(=17 \%)$ \\
A. of the lower leg & 8 & 0 & 0 & $0 / 8(=0 \%)$ \\
\hline \multicolumn{1}{c}{ total } & 47 & $8=17 \%$ & $1=2 \%$ & $7 / 47=15 \%$ \\
\hline
\end{tabular}

Ehringer, H., 1974-03-31.

lysed. In the second group with thrombusage of 6 weeks to 6 months were 47 occlusions. 8 or $17 \%$ have been opened. None of 81 occlusions older than 6 months have been lysed. Early recurrencies of the thrombosis happened in 14 cases during the period of change from fibrinolytic therapy to long term anticoagulation. 13 belong to the first group and 1 to the second group. The final results are $64 \%$ lysis in the first group and $15 \%$ lysis in the second group. These results demonstrate the influence of age of the occlusion beyond any doubt.

If the material is stratified according to the localisation and to the age of the occlusion, the results of Table 2 and 3 are obtained. In the first group aged 6 days to 6 days to 6 weeks 13 occlusions were localized in the aorta or iliac artery, 38 in the femoral artery, 20 in the popliteal artery and 17 in arteries of the lower leg. $92 \%$ of the occlusions in the aorta and iliac artery, $74 \%$ of occlusions of femoral or popliteal artery and $82 \%$ of occ- lusions in arteries of the lower leg were opened. The 13 recurrencies are distributed as followes : 1 in the large arteries, 5 in $\mathrm{fe}^{-}$ moral artery, and 7 in popliteal artery.

In the second group aged 6 weeks to 6 months 9 occlusions were localized in the aorta or iliac artery, 24 in femoral, 6 in popliteal, and 8 in arteries of the lower leg. $33 \%$ of the large arteries, and $17 \%$ of femoral and popliteal artery occlusions have been opened. None of the occlusions of the distal arteries has been lysed. One patient with occlusion of femoral artery had a recurrency. The final results are $33 \%, 13 \%, 17 \%$ and $0 \%$.

In the third group aged more than 6 months there was only one case with occlusion of the aorta. No lysis was observed. Schoop and coworkers had a rate of thrombolysis in occlusion of the aorta and iliac artery of about $30 \%$ even if the age of the occlusion was more than six months. These results demonstrate very distinctly, that the results are the 
Table 4 Late results and recurrencies

\begin{tabular}{|c|c|c|c|c|c|c|}
\hline \multirow{2}{*}{ Site } & \multicolumn{2}{|c|}{ Finally lysed } & \multicolumn{2}{|c|}{ Late Recurrency } & \multicolumn{2}{|c|}{$\begin{array}{lr}\text { Time of } & \text { observation } \\
\text { Total } & \text { Mean } \\
\end{array}$} \\
\hline & $\begin{array}{l}(\mathrm{LTA}) \\
\mathrm{N}\end{array}$ & $\begin{array}{c}\text { Controlled } \\
\mathrm{N}\end{array}$ & $\mathrm{N}$ & time & vessel & patent \\
\hline Aorta + A. Iliaca & $18[4]$ & $14[4]$ & 0 & & $35.7 \mathrm{y}$ & $2.7 \mathrm{y}$ \\
\hline A. Femoralis & $29[3]$ & $29[3]$ & $(=\stackrel{2}{7} \%)$ & $\begin{array}{l}3.2 \mathrm{y}^{*} \\
1.5 \mathrm{y}^{*}\end{array}$ & $67.4 \mathrm{y}$ & $2.3 \mathrm{y}$ \\
\hline A. Poplitea & $11[2]$ & $11[2]$ & $\left(=\begin{array}{l}1 \\
9 \%)\end{array}\right.$ & $5.6 \mathrm{y}^{*}$ & $30.3 \mathrm{y}$ & $2.8 \mathrm{y}$ \\
\hline A. of the lower leg & 14 & 14 & $\begin{array}{c}6 * \\
(=43 \%)\end{array}$ & $\begin{array}{l}0.4 \text { to }^{*} \\
1.1 \mathrm{y}\end{array}$ & $24.2 \mathrm{y}$ & $1.7 \mathrm{y}$ \\
\hline total & $72[9]$ & $68[9]$ & $\begin{array}{c}9 \\
(=13 \%)\end{array}$ & & $157.6 \mathrm{y}$ & $2.3 \mathrm{y}$ \\
\hline
\end{tabular}

* Thrombosis prophylaxis discontinued brackets : number of stenoses included.

Ehringer, H., 1974-03-31.
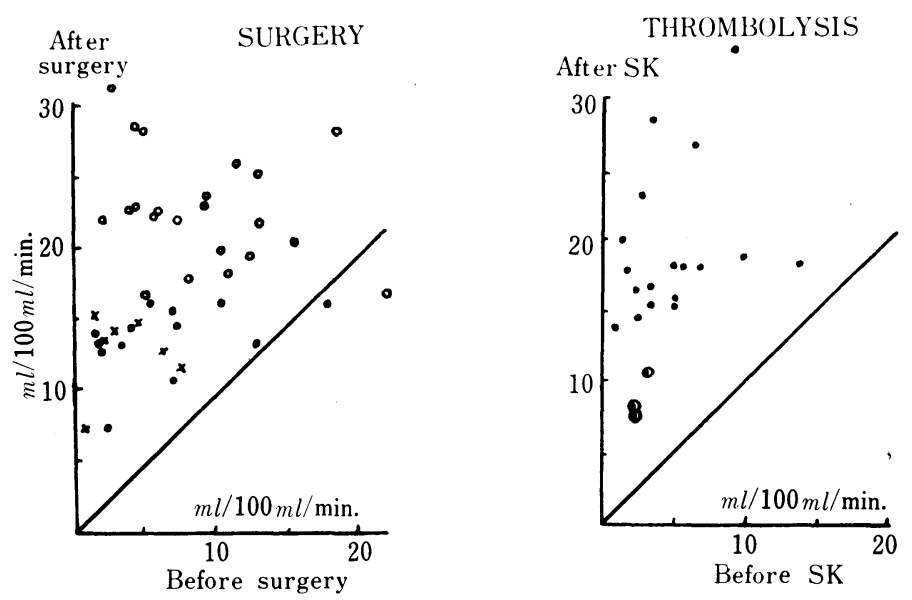

Fig. 1 Arterial reconstruction in femoral occlusions, Effect on peak flow of the calf.

better the larger the occluded vessels are. A few examples may demonstrate our results.

\section{Long time results in not acute ar- terial occlusions.}

After deduction of patients with early recurrencies, there remain 72 occlusions or stenoses in long term observation. 68 cases were followed up for three months to 6.5 years with a mean of 2.7 years, 4 patients died (one by traffic accident, two by myocardial infarction and one by cerebral bleeding). 9 late recurrencies could be observed so far (Table 4) : 2 or $7 \%$ in the femoral artery, 1 or $9 \%$ in the popliteal and 6 or $43 \%$ in the crural arteries. No recurrency was observed in the larger vessels. All the late recurrencies occurred after long time anticoagulant therapy was discontinued for various reasons which again demonstrate the importance of 


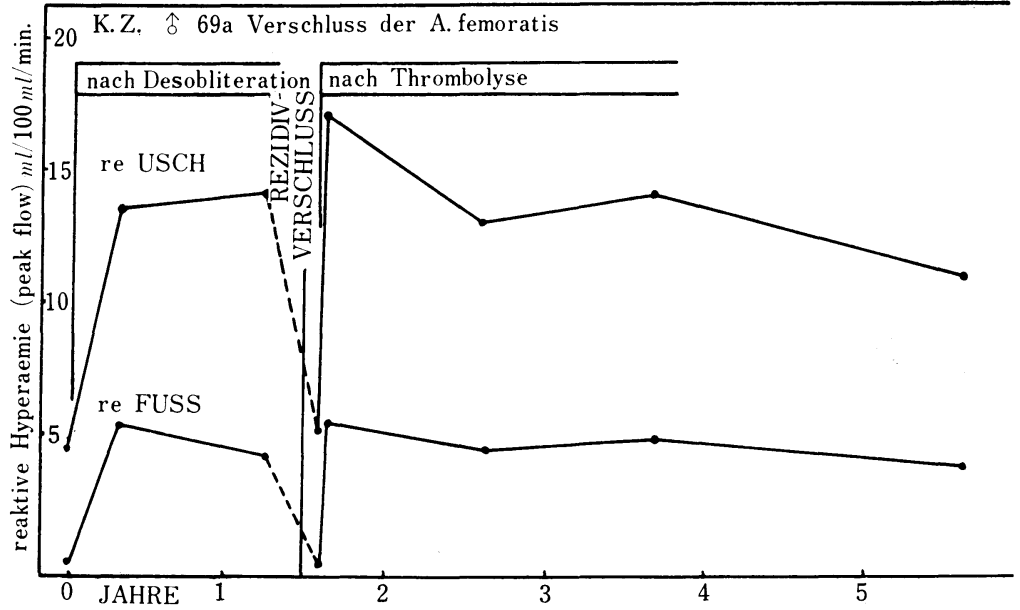

Fig. 2

long time anticoagulation. The good results could be mantained in $87 \%$ of the cases for time periods up to 6.5 years. Similar to the acute results the long time results are the better the larger the formerly occluded vessel was.

\section{Functional results, comparison with surgery.}

The acute functional results after thrombolysis and after arterial surgery were compared in patients treated for femoral arterial occlusions. As parameter of the efficiency of the circulation a standardized test of hyperemia especially the peak flow of the calf after $5 \mathrm{~min}$. arterial arrest was used. The abscissa in Fig. 1 gives the peak blood flow before, and the ordinate the peak flow after SK or surgery in $\mathrm{ml} / 100 \mathrm{~m} l$ tissue/min. In the surgical figure the circles mean ideal reconstructions, the dottes cases where stenoses are left after operation, and crosses represent patients with additional distal arterial occlusions or stenoses. All the values are above the line of indifference and are in a similar range in the two groups.

Especially explanatory is one case in which both types of therapy could be compared (Fig. 2). It is a 69 years old man, in whom the function was studied in the calf and on the foot. After surgical reconstruction of a femoral artery occlusion the peak flow increased to $15 \mathrm{ml} / 100 \mathrm{ml}$ tissue/min. One and half a year later, a recurrency developped, and the patient was treated with SK. The peak flow increased again to $17 \mathrm{~m} l / 100 \mathrm{~m} l$ tissue/min. The vessel is now open for four years.

As you may see in Fig. 3 the acute functional results can be maintained for several years in most of the patients. In some cases a slight decrease of the peak flow is caused by narrowing of the arteries by progressive arteriosclerosis as could be shown by angiographic controls.

\section{Acute arterial occlusions.}

The therapeutic approach in these conditions depends on the degree of ischemia. In severe cases with complete or nearly complete ischemia surgical reconstruction is initiated as quickly as possible, if the localization of the occlusion and the condition of the patients permit it from a technical point of view.

In cases with moderate or mild ischemia 


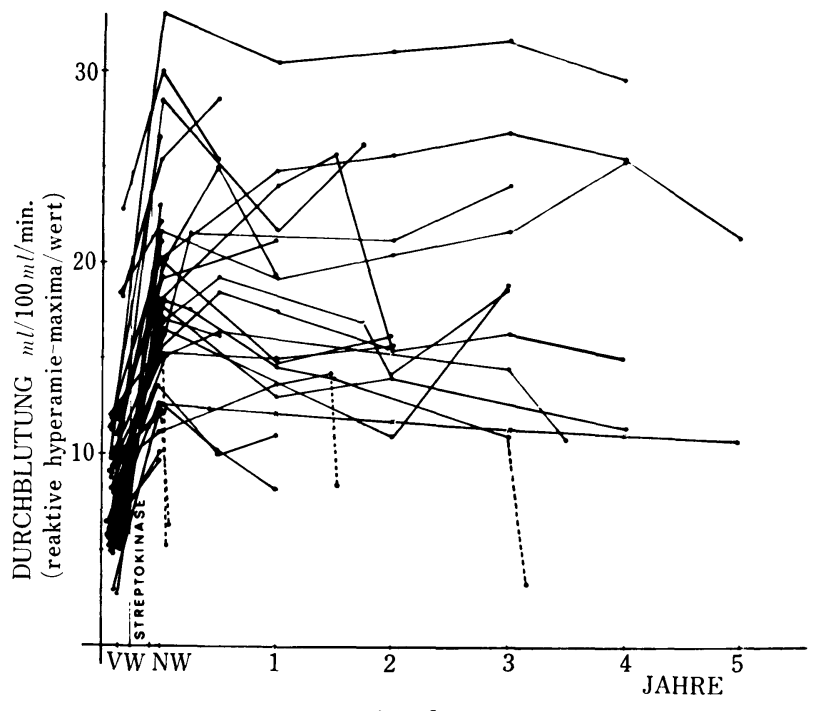

Fig: 3

the therapeutic procedure might be the same as in chronic obliterative arterial diseases. One has, however, to consider that many acute arterial occlusions are caused by emboli originating from the heart. These cases have to be treated by embolectomy whenever possible because of the great risk of initiating further cardiogenic embolization by the treatment with SK.

\section{Side effects and complications.}

The number of side effects of this therapy is high. The complication observed in the first 77 consecutive patients treated by us are discussed in the following paragraph (Table 5).

(1) Temperature rise. An early temperature rise within the first hours of treatment was frequently observed with the older SK-preparations. It was caused by impurities or it was a sign of an allergic reaction. This is avoided by the better purification of the present preparations, and by the use of prednisolon. A late temperature rise over $37.5^{\circ}$ was observed on the second to fourth day in $60 / 77$
Table 5 Side effects of thrombolytic therapy (Ehringer, et al., 1974)

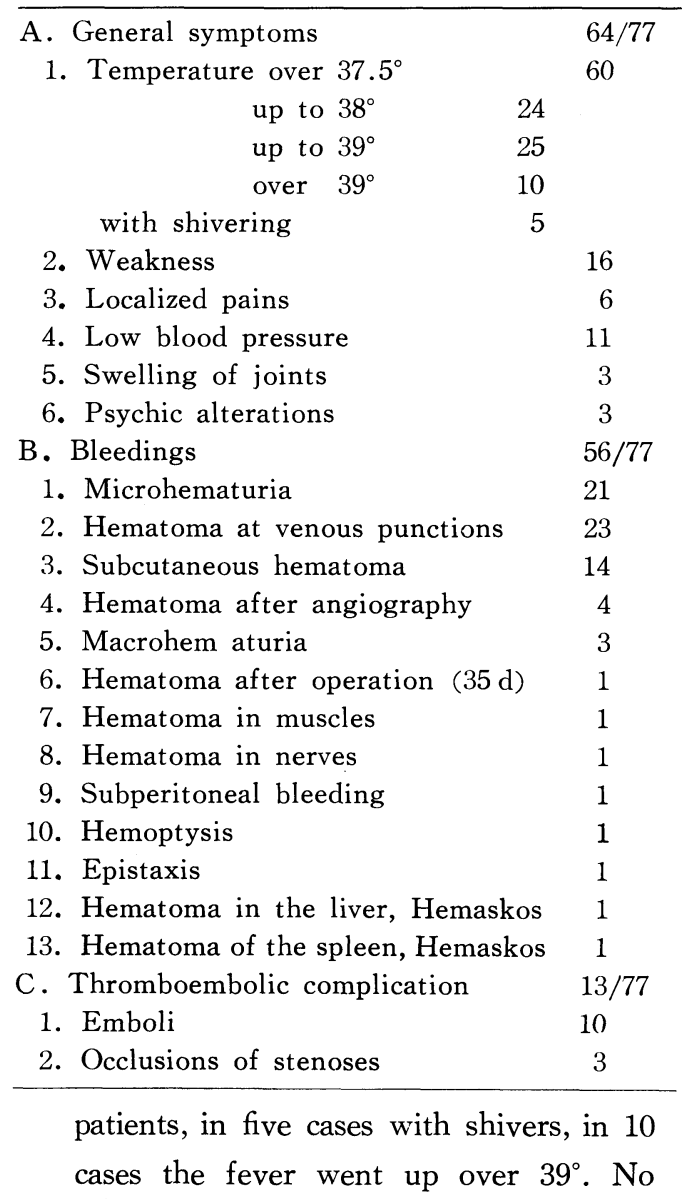


other reason than the SK-infusion could be found in the most cases. A local infection was observed in a few patients on the place of infusion. One patient, not included in this series who was treated for a retinal artery thrombosis, developped a sepsis from which he recovered. The origin of the sepsis was not found, and it may be speculated that thrombi in the wall of unknown foci may be lysed or bacteria included in thrombi come into the circulation. Schoop et al. observed 2 letal cases of sepsis.

(2) General symptoms, such as malaise were observed in 16 , localized pains in muscles and bones in 6 , swelling of joints in 3 patients. One patient developed the signs of acute tonsillitis. These pains and joint swellings may be allergic symptoms caused by SK in patients after streptococciinfections.

(3) Hypotension was observed in eleven patients.

(4) Psychic alterations especially motoric agitation was observed in 3 cases. All these symptoms quickly disappeared after the infusion was stopped.

(5) Bleedings of various severity were observed in 56 of 77 patients. Most of them were from minor importance. A mean reduction of hematocrit of $8 \%$ (hematocrit before treatment taken as 100\%) in all patients was caused by small bleedings into the skin and by diagnostic procedures for the control of therapy. More than $10 \%$ reduction of hematocrit was obser ved in 26 of 77 patients during the SK therapy (mean 13.6\%) and in 15 patients several days after the end of the infusion (up to 20\%).

In detail there was microhematuria in 21 cases, grosshematuria in 3 , hematoma after injections in 23 cases, subcutaneous bleedings in 14, 4 bleedings 1.5 to 7 days after angiography, one bleeding 35 days after operation with venous bypass and rethrombosis, $1 \mathrm{mu}-$ scle bleeding, one bleeding into the nerve, one subperitoneal bleeding, 1 hemoptysis and 1 epistaxis. All these side effects were listed up for reason of completeness. They were not severe in our hands. Two severe complications, however, have been observed when we used Arvin instead of heparin in the change-over phase from SK to anticoagulants. At this time the patients were already in good condition and out of bed. The first case was a 72 years old man. Full coumarin effect was already present and the last Arvin infusion was finished a few hours before, when he developped a subcapsular hematoma of the liver with rupture hemaskos, and suddenly died. The second patient va as a 64 years old man whose vascular occlusion could not be opened. Therefore he was only treated with Arvin after SK for several days and not with dicumarol. He developed subcapsular hematoma of the spleen with rupture, hemaskos and could be saved by splenectomy. It may be speculated that the combination of a blood clotting defect, of hypofibrinogenemia caused by Arvin and the defective fibrin depositions after defibrination which may induce local fibrinolysis, prohibits efficient hemostasis of otherwise unimportant bleedings. The use of Arvin instead of heparin for the period of time between the end of SK-infusion and sufficient oral anticoagulation principally would have the advantage that during the changeover phase no early recurrencies have occurred which results in a better final rate of lysis. Furthermore it could be shown that the reduction of whole blood viscosity was much more pronounced in the combination SK Arvin as compared with SK heparin. Further 
investigations will show whether a smaller dose of Arvin is as well effective in prohibiting early recurrencies as safe and without the incalculable risk of severe bleedings.

(6) Thromboembolic complications. Peripheral emboli could be observed during and after dissolution of arterial thrombi in 13 cases. The largest emboli were observed in 3 patients with thrombosed Dacron-Yprostesis, and inguinal embolectomy was necessary in these cases. The smaller emboli have easily been dissolved by the SK-therapy.

\section{Contraindications}

Each patient has to be scrutinized for contraindications. Those are hemorrhagic diathesis and still active treatment with dicumarol congeners, 7 days after arter arterial punction, 10 days after operations, 14 days after lumbal aortography, 3 to 4 weeks after stroke. Stroke $r \in$ mains to be a relative contraindication even later. Ulcers of the gastrointestinal tract. $\mathrm{X}$-ray examination is made in each case and if there is any doubt on the result, endoscopy is performed. Hypertension over $200 \mathrm{~mm}$ systolic and $110 \mathrm{~mm}$ diastolic is a contraindication, or retinal changes grade 3 and 4. Furthermore patients with fresh infections of any type, endocarditis, embolizing heart failure, severe diseases of parenchymal organs and with cancer are excluded. Age over 70 years was considered as a relative contraindication but now we do not lyse people older than 70 years (Table 6).

\section{Indications}

If an internal angiologist (this means a special experienced physician) is available, thrombolysis might be the treatment of primary choice in the following cases :

(1) All patients with arterial occlusions loca-
Table 6 Contraindications

1. Hemorrhagic diathesis

2. Treatment with dicumarol congeners

3. 7 days after arterial punction

4. 10 days after operations

5. 14 days after lumbal aortography

6. $3 \sim 4$ weeks after stroke

7. Ulcers of the gastrointestinal tract

8. Hypertension : over $200 \mathrm{~mm}$ systolic over $120 \mathrm{~mm}$ diastolic retinal changes grade III and IV

9. Fresh infections of any type

10. Endocarditis

11. Embolizing heart failure

12. Severe diseases of parenchymal organs (liver, kidney)

13. Cancer

14. Patients older than 70 years

15. First trimenon of pregnancy

lized between the distal abdominal aorta and the arteries of the lower leg if the history of claudication is not longer than 6 weeks.

(2) In arterial occlusions localized in the distal abdominal aorta and the iliac arteries with a history of ischemia up to one year.

There are no arguments in favour of surgical treatment in these cases, since functional results and the rate of late rethrombosis are about the same after both types of treatment. The rate of death is $0.8 \%$ in SK treatment as compared with at least $2 \%$ during surgical treatment. Besides this the function may faster deteriorate after failure of vascular surgery and even amputation might the result in some cases.

Acute arterial occlusions with complete ischemia or arterial emboli should primarily be treated by the vascular surgeon.

\section{Discussion}

Our results are in good agreement with those of other groups working with strepto- 
Table 7 Comparison of results of thrombolytic therapy. Duration of occlusion : 6 days $\sim 6$ weeks.

\begin{tabular}{l|c|c|c|c}
\hline \multirow{2}{*}{ Region } & \multicolumn{4}{|c}{ Authors } \\
\cline { 2 - 5 } & $\begin{array}{l}\text { Schoop, } \\
\text { Levy, 1974. }\end{array}$ & $\begin{array}{l}\text { Jester, } \\
\text { et al., 1974. }\end{array}$ & $\begin{array}{l}\text { Heinrich, } \\
\text { Schmutzler, 1972. }\end{array}$ & $\begin{array}{l}\text { Ehringer, } \\
\text { et al., 1974. }\end{array}$ \\
\hline Aorta & - & - & $33 \%$ & \\
A. il. comm. & - & 0 & $43 \%$ & $85 \%$ \\
A. fem. & - & $83 \%$ & $57 \%$ & $61 \%$ \\
A. popl. & - & $40 \%$ & - & $40 \%$ \\
lower leg & - & - & $82 \%$ \\
\hline
\end{tabular}

Duration of occlusion : 6 days $\sim 6$ months

\begin{tabular}{l|c|c|c|c}
\hline Aorta & $27 \%$ & & $33 \%$ & $63 \%$ \\
A. iliaca & $26 \%$ & $25 \%$ & $15 \%$ & $42 \%$ \\
A. fem. & - & $36 \%$ & $36 \%$ & $34 \%$ \\
A. popl. & - & $40 \%$ & - & $56 \%$ \\
lower leg & - & - & - & \\
\hline
\end{tabular}

okinase. The success of that therapy depends

(1) on the skillfull performance of the therapy. The greatest experience is necessary for a seamless change over from fibrinolytic treatment to anticoagulation. Early recurrences may happen at that time.

(2) on the age of the occlusion and

(3) on the size of the occluded vessel. The larger the vessel, and the shorter the duration of the occlusion, the better the results. A comparison of the results obtained by the larger working parties in Europe shows good correlation. Some of the seemingly great differences are obviously caused by differences in the selection of patients and by the small number of cases. Schoop has the largest number of patients ; the age of the arterial occlusions of his patients was between several months and several years, however, that means a selection of patients with really chronic and old occlusions. In this group he found the best results in occlusions of the aorta and iliac arteries. The lysis of occlusions of short duration was most successfull in our group in the large pelvic vessels and in the arteries of the lower legs. The results of the lysis of occlusions in the femoral and popliteal artery were in about the same range in all groups (Table 7 ). The same is true if the results of lysis of occlusions with a duration up to 6 months is considered. The number of late recurrencies was about the same in all groups and more numerous in the smaller vessels (Table 8).

The functional results are the same whether the opening was performed by surgery or by thromblysis, and also in the frequency of late recurrencies there are obviously no large differences. We had in the total material $13 \%$ late recurrencies, Jester et al. $21 \%$, and Lippman (1973) reports on 15 to $39 \%$ occlusions within 3 to 12 years after femoro-popiiteal autologous vein grafting. Bauchhenns (1974) reports on $8 \%$ occlusions of venous bypasses in the calf after 3 to 17 months.

In addition to the medical results the costs of the various types of treatment have to be considered. This question was examined by the administration of Basle University Clinic in Switzerland and it was found that the costs 
Table 8 Comparison of the frequency of late recurrencies.

\begin{tabular}{l|c|c|c}
\hline \multirow{2}{*}{ Region } & \multicolumn{3}{|c}{ Authors } \\
\cline { 2 - 4 } & $\begin{array}{l}\text { Schoop, } \\
\text { Levy, 1974. }\end{array}$ & $\begin{array}{l}\text { Jester, } \\
\text { et al., 1974. }\end{array}$ & $\begin{array}{l}\text { Ehringer, } \\
\text { et al., 1974. }\end{array}$ \\
\hline Aorta & $4 \%$ & - & - \\
A. iliaca & $4 \%$ & $28 \%$ & 0 \\
A. fem. & - & $15 \%$ & $7 \%$ \\
A. popl. & - & $50 \%$ & $9 \%$ \\
lower leg & - & - & $43 \%$ \\
\hline
\end{tabular}

are roughly the same for surgical and medical treatment.

\section{Conclusions}

If the facts discussed above are considered it is quite obvious that thrombolytic therapy with SK should be the treatment of primary choice in all arterial occlusions localized between the distal abdominal aorta and the arteries of lower ieg, if the age of the occlusion is not more than 6 weeks. If the age of the occlusion is more than 6 weeks thrombolytic therapy should only be considered in occlusions of the abdominal aorta and the large pelvic vessels.

To be able to treat occlusive peripheral arterial disease with success at a large scale several prerequisites should be fulfilled. At first special angiologic sections should be found in each medical clinic.

Second tutoring of patients and doctors will be necessary.

The patient should learn to see his doctor immediately when symptoms of claudication develop. The doctors have to be convinced that it is necessary to send the patient early to a medical angiological unit.

\section{Literature}

1) Administration, University Clinic Basle. Jahrestagung der Schweizer Gesellschaft für Angiologie, Basle, 1973.
2) Ardlie, N. G. and Han, P.: Enzymatic basis for platelet aggregation and release: The significance of the platelet atmosphere and the relationship between platelet function and blood coagulation. Brit. J. Haemat., 26 ; 331 356, 1974.

3) Bauchhenss, G. : Erkennung und operative Behandlung chronischer arterieller Durchblutungsstörungen der Beine. Mat. Med. Nordm., 26 ; 70 85, 1974.

4) Deutsch, E. and Fischer, M.: Die Wirkung i. v. applizierter Streptokinase auf Fibrinolyse und Blutgerinnung. Thromb. Diath. haem., 4; 482, 1960.

5) Ehringer, H., Dudczak, R., Hausteiner, H., Widhalm, F. und Lechner, K. : Streptokinasetherapie von Arterienverschlüssen distal des Leistenbandes. Kurz-und Langzeitergebnisse. In: Aktuelle Probleme der Angiologie, Bd. 24, Hans Huber, Bern 1974, 24 42.

6) Ehringer, H., Dudczak, H., Widhalm, F. und Lechner, K. : Wirkung und Möglichkeit einer Defibrinierung in der Therapie arterieller Durchblutungsstörungen (Untersuchungen mit Arvin). In : H. Ehringer (ed.) Fortschritte der konservativen Therapie der peripheren arteriellen Verschlußkrankheit, Aktuelle Probleme in der Angiologie Bd., 24; 110 123, 1974, Hans Huber Verlag, Bern.

7) Ehringer, H., Hausteiner, H., Widhalm, F. and Lechner, K. : Short time results of thrombolytic therapy in not acute arterial occlusive disease. IX. Internat. Congr. An- 
giol. Florence, 1974.

8) Ehringer, H., Hausteiner, H., Widhalm, F. and Lechner, K.: Long time results and functional results of thrombolytic therapy in not acute arterial occlusions. IX. Internat. Congr. Angiol. Florence, 1974.

9) Gottlob, R. und Blümel, G. : Der Einfluß der vier Thrombenalter a uf die Lysierbarkeit mit Streptokinase. Med. Welt, 19; 2627, 1968.

10) Gottlob, R., Blümel, G., Piza, F., Brücke, P. und Böhmig, H. J. : Die Lysierbarkeit operativ gewonnener menschlicher Thromben verschiedenen Alters in Streptokinase. Wr. Med. Wschr., 188; 222, 1968.

11) Gottlob, R., Blümel, G., Piza, F., Brücke, P. and Böhmig, H. J. : Studies on thrombolysis with streptokinase. II. The influence of changes due to age in thrombi and whole blood clots. Thromb. Diathes. haem., 19; 516,1968 .

12) Han, P. and Ardlie, N. G. : Platelet aggregation and release by ADP and thrombin : Evidence for two separate effects of ADP on platelets, involvement of fibrinogen in release, and mechanism of inhibitory action of acetyl-salicylic acid. Br. J. Haemat., 26 ; $357 \sim 372,1974$.
13) Heinrich, F. and Schmutzler, R. : Ergebnisse der Thrombolysebehandlung chronischer Gliedmaßenarterienverschlüsse. Dtsch. Med. J., 23 ; 351 358, 1972.

14) Jester, H., Alexander, K., Poliwoda, H., Wagner, H. H. and Holsten, D. : 5 Jahre Fibrinolyse bei chronischer arterieller Verschlußkrankheit : Kurz-und Langzeitergebnisse. In : Aktuelle Probleme der Angiologie, Bd. 24, Hans Huber Verlag, Bern, 1974, $43 \sim 51$.

15) Lippmann, H. I. : Peripheral vascular disease today. Bull. New York Acad. Med., 49 ; 674, 1973.

16) Schoop, W. und Levy, H. : Streptokinasetherapie chronischer Verschlüsse der Aorta und der Beckenarterien. Kurz-und Langzeitergebnisse. In : Aktuelle Probleme der Angiologie Bd. 24, Hans Huber Verlag Bern 1974, 18 23.

17) Silva, De A., Widmer, L. K., Martin, H. and Ramseier, L. : Longterm anticoagulation in occlusions of peripheral arteries. In : E. Deutsch, K. M. Brinkhous, K. Lechner, S. Hinnom (ed.) Thrombosis: Pathogenesis and clinical trials. Schattauer (Stuttgart), 1974, 253 262.

\title{
末梢動脈閉塞症の血栓溶解療法
}

\author{
E. ドイチェ* H. エーリンガー*
}

（風 間 睦 美**訳）

末梢動脈閉塞の発生頻度や疫学につき得られ るデータでは, 心筋硬塞に関するもの以上に確 立されたものはない、ヨーロッパにおける最大 の疫学的調查は Widmer らが 1959 年以来スイ

* オーストリー国ウィーン大学第一内科

** 帝京大学医学部第一内科, Mutsuyoshi KAZAMA : Ist Department of Internal Medicine, Teikyo University School of Medicine, Tokyo, Japan.
ス Basel の製薬会社の 6400 人の従業員につき 行ったものである.これによると末梢動脈閉塞 は平均年秢50歳の男子に $3 \%, 70$ 歳では $8 \%$ に 見出されるが，これは20歳から70歳の人口の約 $5.1 \%$ が閉塞性末梢動脈疾患に罹患しているこ とを示す.すなわち全世代の人々にとってこの タイプの疾患が高頻度に発生し, かつ極めて重 
大な問題であることを意味する．これらの基礎 的病変の殆どは閉塞性動脈硬化であるが，一方 閉塞性血栓性血管炎や各種の動脈炎はヨーロッ パにおける閉塞性動脈疾患の病因としては極め て少ない，従って本講演では前者についてのみ に論議を絞りたい。動脈硬化は血管の狭窄や内 皮層の損傷をもたらす.血小板は内皮下組織に 粘着し，これにつづいて血小板が凝集し，そし て最後に注白色血栓が形成される。従来血液の 凝固やフィブリンの形成はこの形式の血栓形成 には僅かな役割しか果さないと一般的に考えら れて来た. しかも血小板には抗プラスミンが多 く, 従って動脈血栓では有効な線維素溶解の導 入が期待されないとされている. しかし実地臨 床上の経験はかかる想定とは異なるものであ る. 最近 Ardlie and Han らは血液凝固もま た血小板凝集の過程基本的に関与することを 証明した.コラゲンに粘着した血小板は凝固第 XI因子の活性化能を現わすが（コラゲン誘発性 凝固活性), またそれによって血小板表面で内 因性凝固因子が活性化される。1個の血小板表 面で形成されたトロンビンは他の血小板表面の フィブリノゲン分子と結合する. この結果可逆 性の血小板凝集がもたらされる.

次にフィブリンが形成され, フィブリンポリ マー化によって非可逆的凝集が惹起される.一 方血小板の構成物質すなわち $\mathrm{ADP}$ ，七ロトニ ン, 血小板第 3 , 第 4 因子が放出される. 周囲 の血液中で注さらに多数の血小板が凝集し, 血 液凝固が誘発され. ついには白色血栓が形成さ れて血管は閉塞する. Gottlob らは in vitro で 陳旧度の異なる血栓の溶解性を検討したが, 彼 らは形成直後の血栓は予測通り容易に溶解する 事を観察している.しかし形成後ほぼ 2 日目で は血餅収縮によってプラスミノゲンが失われる 為血栓は溶解抵抗性を示すようになった．第 1 週の終りになると血栓は膨化して液体成分やプ ラスミノゲンをとり込み再び容易に溶解し得る ようになる. 血栓の器質化は従来考えられてい たよりははるかに遅く始まり, また小さい血管 においてのみこれが完成する．しばしば長期間 器質化は血栓の辺縁部分に局限されているにす
ぎない．大動脈や総腸骨動脈のような大血管で は血栓の大部分は月余あるいは年余の間, 器質 化されずに留まる、これらの事実から明らかな ことは,

(1) 抗凝血薬療法や血栓溶解療法は対称的で長 い形の動脈狭窄に無効である, 何故ならそれ は主として血管壁の動脈硬化性肥厚によって 惹起されているからである.

(2) 抗凝血薬療法や血栓溶解療法注動脈閉塞や 壁性血栓に基く非対称的で短い形の動脈狭窄 に対しては有効である.

（3）大きい血管の閉塞は小さい血管よりも容易 に溶解される。

(4) 大血管では高度の陳旧性血栓でも溶解され ることがある。

われわれ自身の症例についてり血栓溶解療法の 成績を示す。

\section{I. 症例および方法}

われわれの症例は 117 例一男子 101 例, 女子 16 例一平均年齢 59 歳で $\mathrm{S} \mathrm{K}$ 療法を行った. そ の中 68 例は平均 2.7 年（3 か月から 6.5 年）の 追跡調查をうけている. 各症例共予めオシログ ラフィー, 踵部血圧 (ドップラー超音波法で測 定), 静脈閉塞脈波, 動脈造影などの 検査を受 け, また全身性検査を行ない, 予想される禁 忌, ことに消化管潰瘍の発見に努めた. 治療効 果は血栓溶解療法が開始されて間もなく，およ び毎年の追跡調査時に上と同じ方法 で検討し た。

血栓溶解は S K の静注で導入された. 当初の 症例については S K の必要投与量は S K 而性試 験で決定されたが，後にはS K 40万単位の基礎 投与量を50分以内に静注すれば線溶活性がルー チンに誘発される事が判った. 線溶活性は 1 万 $\mathrm{u} /$ 時 の静注で維持され, これは機能恢復テス トで動脈閉塞の再開が確かめられるか, 副作用 の為静注中止のやむなきに到るまで続けられた が, たとえ血管の再開が成功しなくとも 144 時 間を超えないこととした. 平均治療持続時間は $71.8 \pm 3.1$ 時間で, 使用した平均 S K 量は $7.9 \pm$ $3.0 \times 10^{6}$ 単位であった. 現在われわれは 72 時 
間を基準投与時間として愛用しているが，その 理由は効果よりも副作用の危険が増大してそれ 以上静注を続ける価值のないことが明らかにな ったからである.静注開始に先立って50mgプレ ドニソロンを投与した. 治療効果は通常卜ロン ビン時間. フィブリノゲン量, Quick 法かトロ ンボテストによるプロトロンビン值でコントロ ールした，そして血中に存在する抗 S K 物質が $\mathrm{S} \mathrm{K}$ によって中和されると直ちに血浆中のプラ スミノゲンアクチベータ活性が証明されるよう になる。これは治療の 終末時点まで維持され る.プラスミノゲンはプラスミンに活性化さ れ，多かれ少なかれ血中から完全に消失する. フィブリノゲンは $100 \mathrm{mg} / \mathrm{d} l$ 以下に減少し, 時 には完全な無フィブリノゲン血状態となる。卜 ロンビン時間は, 流血中に線溶が誘発され, フ ィブリノゲンが減少し，FgDP が生成されるた めすみやかに延長する．トロンビン時間は正常 值の 3 倍を維持するよう努めた.

$\mathrm{S} \mathrm{K}$ 静注の経過中最初に極めて低下したフィ ブリノゲンが再び増加し，また最初非常に延長 したトロンビン時間が短縮する傾向が認められ ることがある.この効果は血中よりのプラスミ ノゲンの消失およびフィブリノゲン分解や F D Pレベルの低下によるものである．時にはフィ ブリノゲンの増加は極めて速やかである．治療 開始後第 3 日目，時にはそれよりもっと早い時 期間々見られることであるが，トロンビン時 間が30秒以内に回復する場合には，フィブリ， ゲンレベルを低下させ，トロンビン時間を 2 倍 に延長させるために S K 投与量を 12 時間倍増す る. 同時にわれわれは内因性血栓溶解能を増強 するよう試みる．トロンビン時間の延長が達成 されない場合にはへパリンを追加する.けだし 血栓再発の危険がこの時点ですでにあり得るか らである.トロンビン時間が 120 秒以上となっ た場合には S K 静注を数時間中止した. このよ うな成績を維持するには血栓溶解療法に続けて 抗凝血薬療法を行なわなければならない。これ が本療法の最も困難な部分である。ヘパリンは $\mathrm{S} K$ 静注終了直後から開始され，1000u/時間の 静注 あるいは 8 時間毎 10,000 から $12,500 u$ の
皮下注射を行った, 同時に phenprocoumon (Marcoumar) 治療を開始した。ヘパリン療法 はプロトロンビン值が治療域に入るや中止し た. 22 例には Arvin すなわちマレー半島の毒 蛇 Agkistrodon rhodostoma の蛇毒をヘパリン の代りに 12 時間毎に 154 単位の間歇静注を行 なった。この場合も marcoumar 療法を同時に 開始し, プロトロンビン值が治療域に入るや Arvin 静注を中止した.

\section{II. 成 績}

\section{1. 急性以外の動脈閉塞症の短期成績}

動脈閉塞 216 を伴う 117 症例が S K 治療をう けた．総計77の閉塞即ち $35.6 \%$ 閉塞が再開通 した。冒頭において既に指摘したように本治療 の成否は, 血栓の陳旧度とその発生部位にかか っている。すなわち症例をその血栓症の陳旧度 に応じて層別化すると，その成績は Table 1 の如くであり, 閉塞88例の陳旧度は 6 日から 6 週の間であったが，この中 69 症例すなわち $78 \%$ の血栓が溶解された. 第 2 群は血栓陳旧度が 6 週から 6 か月の 47 例であった。 8 例即ち $17 \%$ が 再開通した． 6 か月以上の陳旧化閉塞81例では 全く溶解されなかった．血栓の早期再発は14例 で, 線溶療法と長期抗凝血薬療法の切替え時期 に発生した。その中 13 例は第 1 群 1 例が第 2 群 に属する。

最終成績は第 1 群で $64 \%$ ，第 2 群では $15 \% の$ 血栓が溶解された。これらの成績から閉塞の陳 旧度が影響することは疑いの余地がない。

症例を血栓の発生部位と閉塞の陳旧度とから 層別化すると，その成績は Table 2 および 3 の如くである. 第 1 群即ち 6 日から 6 週の群で は13症例の閉塞が大動脈または腸骨動脈に限局 し，38例が大腿動脈，20例が膝窝動脈，そして 17例が下腿動脈の閉塞例であった。大動脈およ び腸骨動脈閉塞つ $92 \%$, 大腿動脈または膝窩動 脈の $74 \%$ ，また下腿動脈閉塞の $82 \%$ が再開通し た。再発 13 例の成績は, 大動脈 1 , 大腿動脈 5 , および膝窩動脈 7 例であった。

第 2 群即ち陳旧度 6 週から 6 か月の群では 9 例の大動脈または腸骨動脈閉塞, 24 例の大腿動 
脈, 6 例り膝窩動脈そして 8 例の下腿動脈の閉 塞が再開通した。大口径動脈の33\%，腸骨およ び膝窩動脈の $17 \%$ が再開通した。それより末梢 の動脈つ閉塞は 1 例も再開しなかった。大腿動 脈閉塞の 1 例が再発した。最終成績は33\%, 13 $\% ， 17 \%$ そして0\%であった。

第 3 群即ち陳旧度 6 か月以上の群では大動脈 閉塞は 1 例のみであった。ここでは 1 例も血栓 溶解が認められなかった。 Schoop らは血栓の 陳旧度が 6 か月以上でも大動脈および腸骨動脈 閉塞の血栓溶解率約 $30 \%$ の成績を得ている。 こ の成績は血管が大きい程成功率がよいことを明 確に示している。症例は少ないが, 我々の成績 もそのような傾向が示されているといえる.

\section{2. 急性以外の大動脈閉塞の長期成績}

早期再発の症例を除いて, 72症例の閉塞また は狭窄の症例に長期間の観察が行われた。 68例 は 3 か月から 6.5 年, 平均 2.7 年の追跡が行わ れ，4例が死亡している.（1 例は交通事故， 2 例は心笳硬塞, また 1 例は脳出血). 現在ま で 9 例に後期再発が認められた（Table 4); 寸 なわち大腿動脈閉塞の中 2 例すなわち $7 \%$, 膝 窩動脈閉塞中 1 例すなわち $9 \%$; 下腿動脈閉塞 6 例すなわち $43 \%$ であった。 大口径動脈には再 発は認められなかった，後期再発の全ては長期 の抗凝血薬療法が何らかの理由で中止された後 に発生しており，このこと注長期抗凝血薬療法 の重要性を証明している．全症例の $87 \%$ につい て㹥 6.5 年間に亘って好成績が得られている. 短期間治療成績と同じく，閉塞血管が大きい程 長期治療成績は良好である。

\section{3. 機能回復効果, 外科療法と比較して}

血栓溶解療法後短期間の成績と動脈外科療法 の成績とを大腿動脈閉塞例につき比較した. 血 液循環効率の指標として充血の標準測定法, 特 に動脈の 5 分 間圧迫停止後 腓腹部の peak flow 值を用いた.

Fig. 1 の横軸には治療前の peak blood flow をとり, 縦軸には S Kまたは外科療法後の peak flow $\mathrm{m} l / 100 \mathrm{~m} l$ 組織/分で表わしている. 外 科的症例の中, 丸印は血管再建が理想的に行わ れたもの, 点印は術後も狭窄が残存したもの,
×印はほかの未梢血管の閉塞や狭窄が併発して いたものを示す．全てり成績がほぼ無相関線よ り上方にあり，両群とも同様な範囲内にある。

二者の療法を比較するに好都合な 1 例を示す (Fig. 2). 症例は 66 歳の男子で血管系の機能 を腓腹部および足部について検討したものであ る. 大腿動脈の閉塞の外科的再建後 peak flow は $15 \mathrm{ml} / 100 \mathrm{~m} l$ 組織/分に迄増加した。 1 年半後 閉塞が再発し。 S K 療法をうけた. peak flow は再び $17 \mathrm{~m} l / 100 \mathrm{~m} l$ 組織/分に迄増加し, 現在 再開通は 4 年間続いている.

Fig. 3 に示すように機能回復の初期成績は大 多数の症例につき数年間は維持されうる. 何例 かにおける peak flow の軽度低下は進行性動脈 硬化に基ずく動脈狭窄によって起こることが動 脈造影による追跡で認められた。

\section{4. 急性動脈閉塞}

この状態に対する治療対策は虚血の程度如何 による．完全なあるいは殆ど完全な虚血を示す 重症例では，手技上の観点から閉塞部位および 患者の状態が許す限り，外科的血管再建を出来 るだけ速やかに開始せねばならない。

中等度あるいは軽度の虚血に対しては治療の 手順注慢性閉塞性動脈疾患に準ずる。しかし急 性動脈閉塞の多くは心臟に由来する塞栓である ことを考慮せね齐ならない，かかる症例ではい かなる場合でも可能な限り塞栓摘出術を行わね ばならない，けだし S K 療法は心由来の栓塞症 をさらに誘発する危険が大きいからである。

\section{5. 副作用ならびに合併症}

本療法の副作用の数は多い．われわれが本療 法を開始して以来最初の77症例につき以下に述 ベる (Table 5).

(1) 体温の上昇. 治療開始後最初の数時間以内 に認められる早期発熱注旧製剤の S K 使用に 際してしばしば認められた。これは不純物に よって惹起されたか，あるいはアレルギー反 応の徴候であった。このようなことはより良 く精製された現在の製剤抢よびプレドニソロ ンの使用で避けられる. $37.5^{\circ} \mathrm{C}$ 以上の後期 発熱は 77 症例中 66 例で第 $2 \sim 4$ 日目にみら れたが, 5 例に戦慄, 10 例では体温は $39^{\circ} \mathrm{C}$ 
以上に上昇した. 多くの症例で $\mathrm{S} \mathrm{K}$ 静注以外 の理由沙出せなかった. 少数例に静注部位 の局所感染が認められた。

この群には属さないが網膜動脈血栓に対す る治療を受けた 1 例で敗血症が現われたが, これは回復させることができた．敗血症の原 因は不明であったが, 未知の感染巣壁の血栓 が溶解されたか, あるいは血栓中に存在した 細菌が流血中に放出された為と想像された。 Schoop らは 2 例の敗血症を観察している.

（2）全身症状たとえば全身倦急感が 16 例に， 筋や骨の局所痛が 6 例に, 関節腫脹が 3 例に 認められた。 1 例は急性扁桃炎を発症した。 これらの疼痛や関節腫脹は溶連菌感染後の患 者に対して S K により惹起されたアレルギー 症状と思われる。

（3）血圧低下は 11 例に認められた。

（4）精神異常ことに多動状態が 3 例に認められ た.これらすべての症状は静注を中止すると すみやかに消失した。

（5）種々の程度の出血が 77 例中 55 例に認めら れた. 大多数はさして重大なものではなかっ た．治療前のヘマトクリット值を $100 \%$ とし た場合, 全症例のへマトクリットの平均減少 は $8 \%$ でこれは皮下の小出血や治療のコン トロールの為に行った診断侵襲によるもので あった. $10 \%$ 以上のへマトクリット值減少 （平均 $13.6 \%$ ）が 77 例中 26 例の S K 療法中 に, $20 \%$ までの減少が 15 例での静注終了後 数日後に認められた.

詳しく述べると，21 例に顕微鏡的血尿， 3 例に肉眼的血尿, 23 例に注射部位の血腫, 14 例に皮下出血，4例に動脈造影術後 1.5 日 から 7 日後に亘っての出血, 1 例には静脈副 血行と血栓再発の術後35日間における出血, 1 例に筋肉内出血, 1 例に神経内出血, 1 例 に腹膜下出血, ならびに喀血および鼻出血各 1 例であった。

これら全ての副作用は完全を期する為記録 されてあるが, われわれの症例で重篤なもの はない. しかしS K 療法から抗凝血薬療法一 の移行期にヘパリンの代りに Arvin を使用
した際， 2 例の重篤な合併症が認められた。 これら患者の状態はすでに良好で, 起床可能 であった．第 1 例は 72 歳の男子で, クマリ ン療法の効果は完全で, 最後のArvin が静注 されて数時間後肝被膜下血腫を形成してそれ が破裂して腹腔内出血を来し, 患者は急死し た. 第 2 例は62歳の男子で（S K 療法でも） 血管閉塞は再開されなかった。したがって患 者は S K 療法終了後数日間 dicumarol の投与. なしに Arvin だけの治療をらけた。脾の被 膜下血腫が現われて破裂し腹腔内出血を来し たが，剔脾によって救命し得た，考えるに凝 固障害, Arvin による低フィブリノゲン血症 および脱フィブリン後のフィブリン形成不全 による局所線溶作用の誘発などが集 積され て, 通常では些細な筈の出血に対する有効な 止血機序が阻止された為であろう．ＳK静注 終了後経口抗凝血薬療法が効果を現わす迄の 期間にヘパリンの代りに Arvin を使用すれ ば，原則的にはこの過渡期での早期再発が阻 止され, ひいては血栓溶解療法の最終成績が 増大するものである.さらに全血の粘度低下 はS K一ヘパリンに比して S K-Arvin の 組合わせの方が一層秀れていることも認めら れている.さらに検討をすすめれば少量の Arvin でも充分に早期再発が防止され, 安全 でありかつ重篤な出血という不測の危険のな いことが明らかにされるかもしれない．

(6) 血栓塞栓の合併 : 末梢への 塞栓が 13 例に おいて動脈血栓の溶解療法中から後にかけて 認められた. 最大の塞栓はダクロン製 $\mathrm{Y}$ 字型 代用血管の血栓症の 3 例に認められ，これら の場合ソケイ部での 栓塞切除が必要であっ た。より小さな塞栓は $\mathrm{S} \mathrm{K}$ 療法で容易に溶解 された。

\section{III. 禁 忌}

各症例についての禁忌を精査せねばならな い.これらは出血傾向があるもの, ダイクマロ 一ル類の積極的治療をうけているもの.動脈穿 刺後 7 日, 手術後 10 日, 経腰性大動脈造影後 14 日, 心笳硬塞発作後 $3 \sim 4$ 週などである. 心筋 
硬塞発作はそれ以後も相対的禁忌である．消化 管の潰瘍も然り．各症例にレ線検查を行ない成 績に少しでも疑点があれば内視鏡を行なう．収 縮期 $200 \mathrm{~mm}$ ，拡張期 $110 \mathrm{~mm}$ の高血症 あるい は網膜変化 3 および 4 度も禁忌である。

さらに如何なる新しい感染, 心内膜炎, 栓塞 性心不全, 実質諸臟器の重篤な疾患おょび癌重 症例は除外される.70歳以上の老齢は相対的禁 忌と見倣されるが，われわれは70歳以上の患者 には溶解療法を行っていない（Table 6).

\section{IV. 適応}

老練な循環器専門の内科医がいる所では血栓 溶解療法は以下の如き場合第 10 選択となる.

（1）腹部大動脈下部と下腿の動脈間の閉塞全 て, 但し疼痛性跛行の既往が 6 週以内の場合を 限る。

（2）腹部大動脈下部と腸骨動脈の間の閉塞, 但し虚血状態が 1 年以内の場合を限る.

かかる症例に対する外科的治療の優越性を支 持する根拠はない，けだし機能的回復の成績や 後期再発率などは外科的, 内科的両療法ともほ ぼ同じだからである。死亡率は S K 療法 では $0.8 \%$ であり，一方外科的療法 では少なくとも $2 \%$ ある.ささらに血管外科療法が失敗すれば 機能低下はより著明で, 時には切断が必要とな る事すらある。但し急性動脈閉塞が完全虚血を 伴った場合や動脈栓塞時は第 1 亿外科医の手に かからねばならない。

\section{V. 考案}

我々の成績は， S K 療法を行なっている他の グループの成績とよく一致している. 治療成績 を左右するものは，

（1）治療を切れ目なく移行させるには充分な 経験が必要である. 早期再発はこの移行期で発 生する.

（2）閉塞の陳旧度であり，しかして

（3）閉塞血管の大きさである．血管が大きい 程, また閉塞の既往が短かい程成績は向上す る.ヨーロッパでの大きな医療チームが上げて いる成績を比較検討すると，よくこの間の相関
を示している。

成績に大きな差異か認められる場合は, 明ら かに症例の選択に差異がある場合か, 症例数が 少ない場合である。

Schoop は最多数の症例を持っている; 彼の 症例の動脈閉塞の陳旧度は数か月から数年にわ たっているが，これは慢性で陳旧性の閉塞症例 が選択されていることになる。

かかる症例群について, 彼は大動脈および腸 骨動脈の閉塞に最も良い成績を上げている，我 我の下では骨盤内大血管および下腿の動脈で, 期間の短かい閉塞の溶解療法に最も成功率が高 い. 大腿おょび膝窩動脈閉塞に対する溶解療法 の成績は何れの治療グルーブでもほぼ同じであ る(Table 7)。

陳旧度が 6 か月迄の閉塞に対する溶解療法の 成績についても同様である.

後期再発率も何れの治療グループでも同じで あり，また後期再発の頻度も大きな差異はない ことが明らかである（Table 8).

我々の全症例では後期再発13\%, Jester らは 21\%であり，Lippman（1973）は大腿膝窩静脈 の自家移植後 3 から 12 年以内に 15 から $39 \%$ の閉 塞を報告している. Bauchhens(1974) は 3 から 17 後に腓腹部静脈副行血行路の閉塞 $8 \%$ を 報告している。

医療上の成績を加えて諸療法の経費も考慮せ ねばならない。この問題はスイス・Basle 大学 クリニックの手による調查が行われたが，外科 的治療でも内科的治療でも経費はほぼ同じであ る.

\section{結語}

今迄論議して来た事実を考慮するならば，明 らかに S K を用いた血栓溶解療法は腹部大動脈 下部から下腿の動脈にかけて局在する全ての動 脈閉塞で，閉塞が 6 週を越えない場合第一選択 治療でなければならない，閉塞の陳旧度が 6 週 を越える場合には，腸部大動脈および骨盤内大 血管の閉塞においてのみ, 血栓溶解療法が考慮 されるべきである.

閉塞性末梢動脈疾患を成功裡に治療する為に 
$7: 108$

は多数の必要条件が満たされねばならない，先 ず各医療機関において特別な循環器部門が確立 されねばならない，次に患者と医師の教育が必 要といえよう.
血液と脈管第 7 巻第 2 号

患者は有痛性跛行症状が現われたなら, 直ち に診療を受けるように教育されねばならず，医 師は患者を循環器専門科に早期のうちに送らね ばならない。

\section{月刊臨床免疫}

年 12 冊 12,000 円 (画含)

第 8 巻第 1 号

(1976 年 1 月)

第 8 巻第 2 号

(1976 年 2 月)

第 8 巻第 3 号

(1976 年 3 月)
$<$ 特集・第 3 回 日本臨床免疫学会総会記録集 $>$

<特集・細狍膜の免疫 $>$

細胞膜の免疫化学 …………………………………野 島 庄 七

細胞膜とホルモン ………………………….......... 原 呉 郎

血球膜抗原 …………………............................ 沢 利 昭

肥満細胞膜の免疫 …………………........................

癌細胞膜の免疫 …………………………………...積 田亭

リンパ球膜の免疫 ………………………………......森 沢 成 司

<特集・補体の一面 $>$

Ig による Alternate Pathway の活性化 …………......藤 田 禎 三

Ig 以外による Alternate Pathway の活性化 …………平 松 誠 —

Alternate Pathway の臨床における意義 …………….. 野 哲 基

各種疾患における抗補体活性 …....波多野 道 信

細胞膜に対する補体の影響 …………………………井 上 公 蔵

補体と抗体産生 …………………………………...田 村 昇

補体と線溶系 …………………………………...近 藤 元 治 